\title{
RESPON HUKUM ISLAM TERHADAP HAK PERLINDUNGAN ANAK UPAYA IMPLEMENTASI SISTEM PERUNDANG-UNDANGAN HUKUM NEGARA
}

\author{
Karmawan \\ Universitas Islam Syekh-Yusuf Tangerang \\ Dpk UIN Syarif Hidayatullah Jakarta \\ Email: karmawan@unis.ac.id
}

\begin{abstract}
Abstrak : Hukum Islam memberikan hak dasar terhadap hak-hak perlindungan anak yang merupakan persoalan mendesak untuk didiskusikan. Mengingat beberapa tahun belakangan ini kita seringkali disuguhi berbagai berita dan informasi tentang berbagai tindak kekerasan terhadap anak yang dilakukan sebagian orang yang seharusnya bertanggung jawab melindungi hak anak. Bahkan terjadi eksploitasi terhadap anak. Hal ini tentu menunjukkan betapa rendahnya perlindungan terhadap anak, meskipun adanya Undang-undang Nomor 23 tahun 2002 tentang Perlindungan Anak. Permasalahan mengenai perlindungan terhadap anak ini bukan saja penting dan mendesak untuk didiskusikan, melainkan juga penting dan mendesak untuk disosialisasikan kepada segala pihak yang bertanggung jawab terhadap perlindungan anak agar mereka memahami hak-hak anak, dan kewajiban mereka untuk memberikan perlindungan, kesejahteraan, dan rasa aman kepada anak. Dan permasalahan anak ini sesuai dengan nilai-nilai maslahat dalam hukum Islam.
\end{abstract}

Kata Kunci : Hukum Islam, Hak Perlindungan Anak 


\section{Pendahuluan}

Anak adalah karunia Allah Yang Maha Kuasa yang harus di syukuri. Anak merupakan penerus garis keturunan yang dapat melestarikan paha bagi orang tua sekalipun orang tua sudah meninggal. Ia adalam amanat Allah yang wajib ditangani secara benar. Karena dalam dirinya melekat, martabat dan hak-hak sebagai manusia yang harus dijunjung tinggi. Hatinya yang suci merupakan permata tidak ternilai harganya, masih murni dan belum terbentuk. Dia bisa menerima bentuk apapun yang diinginkan dan corak manapun yang diinginkan. Jika dia biasakan pada kebaikan dan diajarinya, tentu ia akan tumbuh pada kebaikan dan menjadi orang yang bahagia di dunia dan akhirat. Akan tetapi, jika dia diabaikan dibiarkan seperti layaknya hewan, maka ia akan menderita dan rusak. Karena seorang anak tidak melihat kecuali orangorang di sekitarnya dan tidak meniru kecuali orang-orang disekitarnya pula. ${ }^{1}$

Seorang anak akan menjadi karunia atau nikmat manakala orang tua berhasil mendidiknya menjadi orang baik dan berbakti. Namun jika orang tua gagal mendidiknya anak bukan menjadi karunia atau nikmat melainkan menjadi malapetaka bagi orang tuanya. Oleh sebab itu di dalam Al-Qur'an Allah swt. pernah menyebutkan anak itu sebagai perhiasan hidup dunia, sebagai penyejuk mata atau permata hati orang tuanya. Bersamaan itu pula Allah mengingatkan, anak itu sebagai ujian bagi orang tuanya, bahkan terkadang anak itu bisa berbalik menjadi musuh orang tuanya. Dalam konteks inilah anak memerlukan perlindungan hukum, karena anak, selain merupakan aset keluarga, juga sebagai aset bangsa. Sebenarnya Negara bahkan dunia internasional telah merumuskan aturan tentang perlindungan anak. Hanya saja dalam prakteknya masih belum maksimal. Di sinilah peran agama, dalam hal ini Islam, perlu lebih ditonjolkan mengingat sebagian besar masyarakat kita adalah muslim. Bagaimana Islam menuntun umatnya memberikan pelindungan terhadap anak.

Kedudukan anak memiliki tempat khusus dalam pandangan nilai budaya dan norma yang hidup di tengah masyarakat. Pada satu sisi, anak memiliki hak-hak yang setara dan seimbang dengan orang dewasa. Bahkan pada keadaan dan konteks tertentu, anak memiliki hak-hak yang tidak dimiliki oleh semua orang dewasa. Pada sisi yang lain, anak secara hukum belum dibebani kewajiban seperti yang dibebankan kepada orang dewasa. Selama seseorang masih manyandang status sebagai anak, maka ia tidak dituntut pertanggungjawaban atas perbuatannya. ${ }^{2}$ Keistimewaan tersebut diberikan oleh hukum kepada anak dalam rangka memberikan perlindungan, mengingat keterbatasan dan kelemahan fisik dan psikis yang umumnya dimiliki oleh setiap anak.

Keterbatasan dan kelemahan fisik dan psikis menyebabkan anak memerlukan perlindungan yang memadai agar dia bisa hidup dan mengembangkan dirinya secara baik. Dalam rangka perlindungan anak tersebut, beragam upaya telah dilakukan berbagai pihak sejak waktu yang lama, antara lain dalam bentuk pembuatan perangkat norma moral dan hukum yang tertuang di dalam deklarasi, traktat, dan peraturan perundang-undangan. Bahkan konvensi Hak-Hak Anak Tahun 1989 telah diterima dan diratifikasi oleh Indonesia melalui Presiden No. 36 Tahun 1990 tanggal 25 Agustus 1990. Hal ini berarti pemetintah Indonesia secara hukum berkewajiban melindungi dan

\footnotetext{
${ }^{1}$ Sholihah and Ag, "Perlindungan Anak Dalam Perspektif Hukum Islam."

${ }^{2}$ Bismar siregar, Aspek Perlindungan atas Hak-hak Anak: Suatu Tinjauan, dalam
} Hukum dan hak-hak Anak (Jakarta: Rajawali, 1986), 3. 
memenuhi hak-hak anak, baik hak-hak sipil, politik, sosial, ekonomi, maupun budaya, sebagaimana yang diatur dalam konvensi tersebut. ${ }^{3}$

Pelaksanaan perlindungan anak yang baik dapat diselenggarakan jika memenuhi berbagai persyaratan, seperti pemahaman yang baik dari partisipan, kerjasama dan koordinasi semua pihak, kebijakan dan perencanaan kerja yang matang, kepastian hukum, perlindungan mencakup berbagai bidang, memberikan kemampuan dan kesempatan kepada anak untuk melindungi diri sendiri, perlindungan mesti bersifat preventif, didasarkan kepada hak dan kewajiban asasi, serta memiliki dasar-dasar filosofis, etis, dan yuridis yang diambil dari pancasila, UUD, ajaran agama, nilai sosial, dan sebagainya. ${ }^{4}$

Banyak persoalan yang harus dikerjakan pemerintah untuk hukum perlindungan anak, di dalamnya meliputi persyaratan kelengkapan aturan hukum, kemampuan aparat yang bertugas untuk perlindungan anak, dan juga kesadaran masyarakat atas hak-hak anak. Undang-Undang Dasar 1945 melalui Pembukaan Alinea Ke Empatnya mengamanatkan kepada pemerintah untuk melindungi segenap bangsa Indonesia dan seluruh tumpah darah Indonesia; memajukan kesejahteraan umum; mencerdaskan kehidupan bangsa; ikut melaksanakan ketertiban dunia berdasarkan kemerdekaan, perdamaian abadi dan keadilan sosial.

Dari amanat tersebut di atas menunjukkan bahwa sumber idealisme dan arah kebijakan pemerintah harus melindungi keutuhan bangsa dan negara serta peduli terhadap peningkatan kwalitas kehidupan segenap warga masyarakatnya. Anak sebagai generasi penerus bangsa yang secara alami masih sangat rawan terhadap hambatan dan tantangan dalam kehidupannya tentunya mendapat tempat yang paling penting untuk mendapat protek atau perlindungan oleh pemerintah, terutama agar dalam proses pertumbuhannya dapat menjadikannya manusia dewasa yang tangguh, dan terandalkan untuk menjadi komponen bangsa Indonesia mendatang Jika ada ungkapan bahwa anak adalah titipan Tuhan yang harus dijaga tentunya ungkapan tersebut bukanlah ungkapan tanpa makna. Pada waktu dilahirkan anak memberikan kepercayaan sepenuhnya pada kedua orang tua untuk mengasuh dirinya. Anak tidak pernah berprasangka bahwa orang tua merekalah yang justeru menghancurkan hidup mereka. Demikian juga harapan setiap anak terhadap orang dewasa yang ada disekitarnya. Mereka percaya sepenuhnya bahwa tidak ada seorangpun yang akan menyakiti dirinya. Alam menitipkan si mungil pada orang dewasa karena tidak seperti kebanyakan binatang, manusia membutuhkan waktu lama untuk dapat mandiri. Namun demikian jika memperhatikan pemberitaan diberbagai media massa, sering kali terjadi kekerasan terhadap anak, dan kejadiannya hamper merata seluruh wilayah di Indonesia. Dalam hal ini, penulis ingin mengkaji lebih spesifik tentang respon hukum Islam terhadap hak perlindungan anak dalam hukum negara, sebagai unit terbesar dalam mengelola masyarakat, yang memegang peranan yang sangat penting dalam pembentukan masyarakat dan perubahan sosial yang lebih besar. Hak-hak perlindungan anak dalam keluarga dan masyarakat, dapat dilihat dari ketentuan tentang kewajiban kelurga dan lingkungan terhadap anak.

\footnotetext{
${ }^{3}$ PBB, Konvensi Hak-hak Anak, 20 Nopember 1989.

${ }^{4}$ Arif Gosita, Masalah Perlindungan Anak (Jakarta: Akademika Prssindo, 1985), 1921.
} 


\section{Pembahasan}

\section{Diskursus Hak Perlindungan Anak}

Kamus besar bahasa Indonesia, kata hak diartikan sebagai kekuasaan yang benar atas sesuatu atau untuk menuntut sesuatu. ${ }^{5}$ Dan dalam kamus Ilmiah Populer hak mempunyai arti yang benar, tetap dan wajib, kepunyaan yang sah. ${ }^{6}$ Pengertian hak adalah segala sesuatu yang diperoleh atau dimiliki dan apabila tidak diperoleh maka berhak untuk menuntut. Adapun kata anak dalam kitab Undang-Undang Hak Asasi Manusia 1999 dan Undang-Undang tentang Unjuk Rasa, anak didefinisiskan sebagai manusia di bawah 18 tahun dan belum menikah, termasuk anak dalam kandungan. ${ }^{7}$ Apong Herlina yang dikutip Mushlihin menjelaskan bahwa hak anak dari arti kata hak dan anak tersebut, bahwa segala sesuatu yang harus didapatkan atau diterima oleh anak dan apabila tidak diperoleh, anak berhak menuntut hak tersebut. Dalam hal ini yang yang wajib memenuhi, menjamin serta melindungi adalah orang tua, keluarga, masyarakat dan pemerintah. ${ }^{8}$

Hak-hak anak dalam Undang-undang Nomor 23 tahun 2002 tentang perlindungan anak menjelaskan bahwa hak anak yang dicantumkan meliputi hak untuk dapat hidup tumbuh, berkembang dan berpartisipasi serta mendapat perlindungan dari kekerasa dan diskriminasi, hak atas suatu nama sebagai identitas diri dan status kewarganegaraan, hak untuk beribadah menurut agamanya, berpikir dan berekspresi sesuai dengan tingkat kecerdasan dan usianya, dalam bimbingan orang tua, hak untuk mengetahui, dibesarkan dan diasuh oleh orang tuanya sendiri, hak memperoleh pelayanan kesehatan dan jaminan sosial sesuai dengan kebutuhan fisik, mental, spiritual dan sosial, hak memperoleh pendidikan dan pengajaran dalam rangka pengembangan pribadinya dan tingkat kecerdasannya sesuai dengan minat dan bakatnya, hak menfdapatkan pendidikan khusus bagi anak unggul dan pendidikan luar biasabagi anak cacat, hak menyatakan dan didengar pendapatnya. Hak menerima, mencari dan memberikan informasi sesuai dengan tingkat kecerdasan dan usianya demi pengembangan dirinys sesuai dengan nilai susila dan kepatutan, hak untuk beristirahat dan memanfaatkan waktu luang, bergaul dengan anak sebaya, bermain, berekreasi dan berkreasi sesuai minat dan bakat dan tingkat kecerdasannya demi pengembangan diri dan lain-lain.

Bahkan dalam Deklarasi kairo 1990. Pada pasal 7 tentang Hak Anak dan Orang tua, diatur tentang hak perawatan, pendidikan, kesehatan, kekuatan moral, dan pemenuhan kebutuhan dari orang tua, masyarakat dan Negara, hak orang tua untuk menentukan pendidikan anaknya dengan penuh perhatian demi masa depan anak sesuai etika dan syari'at. Terkait dengan prinsip HAM dalam Islam, dijelaskan dalam konsep al-dharuriyat al-khams sehingga hak anak, secara garis besar meliputi hak-hak tentang agama, jiwa, harta, kehormatan dan keturunan, serta akal. Hak-hak pokok tersebut kemudian diperinci dan dikembangkan sesuai perkembangan kehidupan manusia.

${ }^{5}$ Tim Penyusun Kamus Pusat Pembinaan dan Pengembangan Bahasa, Kamus Besar Bahasa Indonesia (Jakarta : Balai Pustaka,1994).

${ }^{6}$ Pius A Partanto dan M Dahlan Al Barry, Kamus Ilmiah Populer (Surabaya: Arkola, 1994).

${ }^{7}$ Undang-Undang HAM 1999 dan Undang-Undang tentang Unjuk Rasa (Bandung: Citra Umbara, 2000).

${ }^{8}$ Apong Herlina dkk dan UNICEF, Perlindungan Anak (Jakarta: tp , 2003). 
Jelasnya bahwa Hak anak yang dimaksud adalah kekhususan bagian untuk anak dan segala sesuatu yang terkandung dalam syari'at Islam berupa kebutuhan-kebutuhan pokok yang menjamin persamaan hak asasinya dan kebahagiaan hidupnya dalam kedamaian dalam masyarakat Islam dan lainnya. ${ }^{9}$

Rumusan yang lebih konkrit dapat dilihat antara lain pada Undang-undang Nomor 23 Tahun 2002 tentang perlindungan Anak. Pasal 2 ayat (1) undang-undang tersebut menyebutkan bahwa yang dimaksud perlindungan anak adalah segala kegiatan untuk menjamin dan melindungi anak dan hak-haknya agar dapat hidup, tumbuh, berkembang, dan berpartispasi secara optimal sesuai denhgan harkat dan martabat kemanusiaan, serta mendapat perlindungan dari kekerasan dan diskriminasi (pasal 1 angka 2). ${ }^{10}$ Perlindungan tersebut diberikan kepada setiap anak selama dalam pengasuhan orang tuanya, wali, atau pihak manapun yang bertanggungjawab atas pengasuhan, di mana anak berhak mendapatkan perlindungan dari perlakuan diskriminasi, eksploitasi ekonomi ataupun seksual, penelantaran, kekjaman, penganiayaan dan kekerasan, ketidakadilan dan perlakuan salah lainnya. ${ }^{11}$

Rumusan the Convention on the Right of the Child (CRC) yang di adopsi dalam pasal 2 Undang-undang nomor 23 tahun 2002 tentang perlindungan anak, ada empat prinsip penyelenggaraan perlindungan anak, pertama, prinsip non-diskriminasi (non discrimination), kedua, prinsip kepentingan terbaik bagi anak (the best interest for the child), ketiga, hak hidup, kelangsungan hidup dan perkembangan (the right to life, survival and development), keempat, penghargaan terhadap pendapat anak (respect for the views of the child). Di dalam khasanah keilmuan Islam, prinsip perlindungan anak, tidak hanya terbatas kepada empat prinsip tersebut, namun masih ada prinsip lainnya yang dapat digali dari ajaran Islam. ${ }^{12}$

Uraian tentang perlindungan anak dapat dirunut dari pembahasan tentang hakhak manusia secara umum yang terdapat dalam kajian-kajian teori maqashid al-syari'ah (tujuan-tujuan syari'at Islam). Berdasarkan penjelasan ulama bahwa syari'at Islam diturunkan Allah dengan tujuan menjamin kemaslahatan manusia, baik di dunia maupun diakhirat. Tujuan syari'at Islam tersebut akan dapat dicapai dengan memberikan jaminan kepada hak-hak dasar manusia, termasuk tentunya hak-hak anak. Ada lima pilar pokok kehidupan manusia yang harus dijamin dan dipelihara (aldharu $>$ riya $>$ t al-khams), yaitu agama, jiwa, keturunan, dan akal sehat. Semua bentuk dan macam hak yang dimiliki manusia pada hakekatnya dapat dikembalikan kepada dan

${ }^{9}$ Rafat Farid, al-Islam wa huquq al-Thifi, (Kairo: dar Muhaysin, 2002), 9.

${ }^{10}$ Undang-undang Republik Indonesia Nomor 23 tahun 2002 tentang Perlindungan Anak, beserta penjelasannya, (Bandung: Citra Umbara, 2003), 4.

${ }^{11} \mathrm{CRC}$ atau konvensi Hak Anak (KHA), adalah perjanjian yang mengikat secara yuridis dan politis di antara berbagai negara yang mengatur hal-hal yang berhubungan dengan hak anak. Konvensi atau konvenan adalah kata lain dari treaty (traktat), merupakan perjanjian di antara beberapa negara yang mengikat secara yuridis, dan politis. Karena itu konvensi merupakan suatu hukum internasional atau "Instrument Nasional" dengan kata lain hak anak merupakan bagian internal dari HAM, dan KHA merupakan bagian integral dari instrument internasional di bidang HAM. Baca: Unicef, Pengertian Konvensi Hak Anak (Jakarta: Harapan Prima, 2004), 2-4.

12 Ibn Anshari, Perlindungan Anak Menurut Perspektif Islam (Jakarta, Komisi Perlindungan Anak Indonesia), 21. 
pengembangan dari kelima hak pokok manusia tersebut. ${ }^{13}$ Secara tegas Suhail Husein Al-Fatlawi menjelaskan bahwa syari'at Islam diturunkan semata-mata untuk memelihara hak-hak manusia. Setiap bagian dan aturan hukum yang ada di dalam syari' at, baik di bidang ibadah, muammalah, atau hubungan sesama manusia, dibuat untuk menjamin hak-hak manusia pada aspek yang berbeda-beda. ${ }^{14}$

Perlindungan syari'at Islam terhadap hak-hak manusia, secara garis besar, dikategorikan kepada du a bentuk, pertama, jaminan terwujudnya hak-hak manusia sehingga dapat dinikmati oleh orang yang bersangkutan (min janib al-wujud). Kedua, melindungi hak-hak manusia dari berbagai pelanggaran (min janib al-'adam). ${ }^{15}$ Perwujudan pemeliharaan kemaslahatan kelima pilar pokok juga bertingkat-tingkat sesuai dengan tingkat urgensinya. Dalam hal ini, al-syathibi membaginya kepada tiga tingkatan. Pertama, kemaslahatan al-dharuriyyah, yaitu kemaslahatan mendasar yang harus terwujud demi menjada eksistensi kelima pilar pokok kehidupan manusia dan menghindari kehancuran dan kerusakan kehidupan manusia. Kedua, kemaslahatan alhajjiyyah, yaitu kemaslahatan yang harus terwujud untuk memberikan kelapangan, kemudahan, dan menghindari kesempitan hidup manusia. Ketiga, kemaslahatan altahsiniyyah, yaitu kemaslahatan untuk memperindah dan menyempurnakan kehidupan manusia. $^{16}$

Kata hak berasal dari bahasa Arab yang secara etimologis mengandung makna menetapkan dengan kepastian dan menetapkan dengan penjelasan, dan kewajiban. Dalam kamus Lisan al-'Arab kalimat hak diartikan dengan ketetapan, kewajiban, yaqin, yang patut dan yang benar. Lawan kata hak dari segi makna adalah kebatilan, yakni kesalahan. Dan bathil bermakna ketidakbenaran, ketidakadilan, atau bertentangan

13 Tentang teori maqashid al-syari'ah, lihat antara lain: Abu Ishaq al-Syathibi, alMuwafaqat fi Ushul al-Syari'ah, (Kairo: Musthafa Muhammad, tt), Abu Hamid al-Ghazali, alMustashafa fi 'ilm al-Ushul (Beirut: Dar al-Kutub al-Ilmiyyah, 1983), Fathi al-Durraini, alManahij al-Ushuliyyah fi Ijtihad bi al-Ra'yi fi al-Tasyri (Damaskus: Dar al-Kitab al-Hadits, 1975), 28, dan Muhammad Khalid Mas'ud, Islamic Legal Philosophy (Islamabad: Islamic Research Institut, 1977), 223.

${ }^{14}$ Suhail Husein al-Fatlawi, Huquq al-Insan fi al-Islam (Beirut: Dar al-Fikr al-`Arabi, 2001), cet. 1,5 .

${ }^{15}$ Kajian tentang maqashid al-syari'ah, kedua bentuk perlindungan terhadap hak-hak manusia selalu dibahas karena menyangkut hak dasar yang harus dipenuhi baik dalam keluarga maupun lingkungan masyarakat. Bahkan dengan sangat jelas bahwa hukum Islam memberi perhatian yang besar mengenai pemeliharaan dan perlindungan anak. Hal ini dapat dilihat dari beberapa nash al-Qur'an dan Hadits yang berkenaan dengan hak-hak anak, sebagai dasar pijakan pelaksanaan perlindungan anak karena hakikat perlindungan anak adalah pemenuhan hak-hak anak.

${ }^{16}$ Kemaslahatan al-dharuriyyah seperti halnya larangan pembunuhan untuk menjamin terpeliharanya kehidupan, bekerja untuk mendapatkan nafkah yang harus terpenuhinya kebutuhan keluarga, dan perkawinan untuk kemaslahatan keturunan agar terjaga dan terpeliharanya keturunan yang baik. Kemaslahatan al-Hajiyyah, seperti halnya pemenuhan pendidikan dan sekolah, mengkonsumsi makanan yang halal dan bergizi halalan thoyibah. Kemaslahatan al-tahsiniyyah, pelaksanaan aqiqah bayi yang baru lahir, tehnik, membaca, menabung atau berolahraga. 
dengan kebenaran. ${ }^{17}$ Bahkan pengertian yang sama dijelaskan Muhammad Farid Wajdi dalam Dairah Ma'arif al-Qur'an 'Isyrin memberikan pengertian bahwa makna hak cenderung mengandung arti yang sama dengan penjelasan sebelumnya. ${ }^{18}$

Secara terminologis menurut syaikh 'Abd al-Halim al-Luqnawi sebagaimana dikutip wahbah al-Zuhaily yang mendefinisikan kata hak dengan suatu hukum yang ditetapkan secara syarak. Sedangkan, Syaikh Ali al-Khafifi menjelaskan bahwa kalimat hak sebagai kemaslahatan yang diperoleh secara syarak. ${ }^{19}$ Mustafa Ahmad al-Zarqa' dalam kitabnya al-Madkhal al-Fiqhy al-'am: al-Fiqh al-Islami fi Tsaubih al-Jadid memberikan definisi lebih lengkap, yakni suatu kekhususan di mana dengan kekhususan itu syarak menetapkan kekuasaan atau tanggung jawab. Kalimat hak juga merupakan ungkapan kebalikan dari kewajiban yang mengandung arti sesuatu yang dianggap sebagai hak bagi seseorang, maka menjadi kewajiban bagi orang lain. Misalnya hak rakyat adalah kewajiban yang harus dilakukan oleh pemerintah dan hak orang yang berpiutang merupakan kewajiban orang yang berhutang.

Jadi yang dimaksud dengan hak anak adalah kekhususan bagian untuk anak dan segala sesuatu yang terkandung dalam syari'at Islam berupa kebutuhan-kebutuhan pokok yang menjamin persamaan hak asasinya dan kebahagiaan hidupnya dalam kedamaian dalam masyarakat Islam lainnya. Tentunya hak anak memiliki kriteria yang berbeda dengan hak orang dewasa. Hak yang berlaku pada orang dewasa beriringan dengan kewajiban-kewajiban tertentu yang harus dipenuhinya. Namun hak yang berlaku bagi anak-anak tidak terikat dengan kewajiban-kewajiban mandiri tertentu. Artinya, kekhasan hak anak terletak pada pemenuhan hak-hak anak sebagai kewajiban sepihak dari orang tua atau orang yang bertanggungjawab terhadap dirinya, tanpa kewajiban imbal balik dari si anak memenuhi kewajibannya secara pribadi dan mandiri terhadap hak-hak orang tua atau orang yang bertanggung-jawab atas dirinya. Kesan bahwa anak juga memiliki kewajiban hanyalah merupakan bagian dari upaya mendidik anak agar menjadi pribadi yang bertanggung-jawab kelak bila ia telah dewasa. Karena itulah pelaksanaan kewajiban atas seorang anak disesuaikan dengan tingkat pertumbuhan dan perkembangan seorang anak, dan dilakukan dalam bimbingan dan pengawasan orang dewasa. Bahkan bila anak telah mencapai usia baligh sekalipun, kewajiban-kewajiban tertentu yang telah dibebankan atas dirinya tetap memerlukan bimbingan dan pengawasan dari orang dewasa hingga mencapai usia baligh. ${ }^{20}$

\section{Hukum Islam terhadap Hak Perlindungan anak}

Konsep hak perlindungan anak secara umum, bahwa hak-hak anak yang terdapat dalam Undang-Undang Perlindungan Anak sejalan dengan hak-hak anak dalam hukum Islam. Namun, sebagaimana dijelaskan di atas, Undang-Undang Perlindungan Anak tidak memberikan penekanan yang tegas akan hak anak untuk memperoleh

${ }^{17}$ Ibn Manzhur, Lisan al- 'arab (Mesir: Dar al-Mishriyah li al-Ta'lif wa al-Tarjamah, tt), Juz. 11, 332-343

${ }_{18}$ Muhammad Farid Wajdi, Dairah al-Ma'arif al-Qarn al-'Isyrin (Beirut: Dar alMa'rifah, 1971), Cet. III, 465.

${ }^{19}$ Wahbah al-Zuhaily, al-Fiqh al-Islami wa Adilatuhu (Damsyik: Dar al-Fikr, 1409 H/1989 M), Cet. III, 8-9.

${ }^{20}$ Rafat Farid, al-Islam wa Huquq al-Thifi (Kairo: Dar Muhaysin, 2002), 9. 
pendidikan dan bimbingan agama dari orang tua mereka dan bentuk perlindungan anak dalam keluarga juga belum dirumuskan secara jelas. Pasal 6 Undang-Undang ini menyatakan bahwa "setiap anak berhak untuk beribadah menurut agamanya, berpikir, dan berekspresi sesuai dengan tingkat kecerdasan dan usianya, dalam bimbingan orang tua". Pasal ini mengandung ketentuan yang lebih menekankan pada "kebebasan anak" (termasuk dalam masalah agama), bukan pada kewajiban orang tua untuk membimbing anak-anak mereka. Hal ini diperkuat dengan tidak adanya ketentuan yang berkaitan dengan kewajiban orang tua untuk membimbing anak-anak mereka dalam hal agama, sebagaimana dirumuskan pada Pasal 26 Undang-Undang ini.

Islam, sebagai agama yang mempunyai ajaran yang komprehensif, memberikan perhatian yang besar terhadap kehidupan, bahkan ketika manusia masih berbentuk janin. Meskipun manusia masih berada dalam kandungan, Islam memberikan hak-hak yang wajib dipenuhi olah orang tuanya. Dalam hal ini, sebagaimana lazimnya setiap ada hak bersamaan dengan adanya kewajiban, adanya hak-hak anak tersebut bersamaan dengan adanya kewajiban. Hak-hak anak merupakan kewajiban bagi orang tuanya, dan sebaliknya kewajiban anak merupakan hak-hak yang semestinya diperoleh orang tuanya. $^{21}$

Dalam berbagai literatur hukum Islam (fiqh) klasik, tidak ditemukan satu istilah khusus untuk pengertian perlindungan anak. Beberapa literatur hukum Islam (fiqh) klasik menggunakan istilah hadhānah dalam pengertian yang mendekati makna perlindungan anak. Jika ditelusuri dari asal makna katanya, secara bahasa (etimologis), hadhānah merupakan bentuk masdar, yang mengandung arti "memelihara dan mendidik anak". Kata ini berasal dari al-hidhn, yang berarti al-janb (lambung atau rusuk), karena seorang ibu yang menjadi hādhinah (pelindung) mengumpulkan anakanak di lambung (pangkuan)-nya. Adapun menurut istilah, hadhānah berarti memelihara anak kecil, orang yang lemah, orang gila atau terganggu jiwanya, atau yang tidak memiliki kemampuan untuk mandiri; memenuhi pendidikan dan berbagai kebutuhannya, berupa kebersihan, makanan, dan berbagai kebutuhan yang diperlukan untuk kesejahteraan hidupnya. ${ }^{22}$

Hal lain yang nampak terdapat perbedaan antara Undang-Undang Perlindungan Anak dan hukum Islam berkenaan dengan hak anak, ialah tidak disinggungnya hak anak untuk memperoleh warisan dari orang tuanya. Akan tetapi, menurut penulis, tidak dicantumkannya ketentuan mengenai hak seorang anak untuk memperoleh warisan dari orang tuanya, disebabkan oleh perspektif yang digunakan Undang-Undang ini dalam melihat kedudukan seorang anak dalam lingkup yang luas (bukan hanya dalam wilayah domestik (keluarga), melainkan juga dalam wilayah publik), maka pembahasan ketentuan yang berada pada wilayah domestik (kelurga) menjadi tidak detail dan jelas. ${ }^{23}$

Implementasi Hak Perlindungan Anak dalam hukum Islam terhadap pemenuhan hak dasar anak merupakan bagian integral dari implementasi pemenuhan hak asasi manusia. Dalam perspektif Islam hak asasi anak merupakan pemberian Allah

${ }^{21}$ Sholihah and Ag, "Perlindungan Anak Dalam Perspektif Hukum Islam," 2.

${ }^{22}$ Abdurrahman al-Jaziri, Kitab al-Fiqh ‘alā al-Mazāhib al-Arba`ah (Kairo: Dar alHadits, Tanpa Tahun), J. IV, h. 582.

${ }^{23}$ Anak and Hukum, "Perbandingan Hak-Hak Anak Menurut Undang- Undang Nomor 23 Tahun 2002 Tentang Perlindungan Anak Dan Hukum Islam.” 
yang harus dijamin, dilindungi, dan dipenuhi oleh orang tua, keluarga, masyarakat, pemerintah dan negara. Berarti bahwa hak anak yang seharusnya dapat terpenuhi dengan baik bukan hanya merupakan tanggung jawab kedua orang tua tetapi juga merupakan tangggung jawab seluruh aspek masyarakat disekitar lingkungan anak. Dalam terminologi ushul fiqh, perlindungan hukum terhadap hak anak selaras dengan tujuan hukum (maqasid al-shari'ah), yakni terhadap lima aspek (al-kulliyat al-khams atau ad-daruriyah al-khams). ${ }^{24}$ Lima aspek perlindungan itu mencakup agama (hifz addin), jiwa (hifz an-nafs), akal (hifz al-aql), keturunan (hifz an-nasl), harta (hifz al-mal). Ini menegaskan bahwa hukum Islam datang ke dunia membawa misi perlindungan yang sangat mulia, yaitu sebagai rahmat bagi seluruh manusia di muka bumi (QS. Yunus [10]: 57; QS. al-Anbiya' [21]: 107). Pembuat syari'ah (Allah dan Rasul-Nya) menetapkan syari'ah bertujuan untuk merealisasikan kemaslahatan umum, memberikan kemanfaatan, dan menghindarkan kemafsadatan bagi umat manusia. ${ }^{25}$ Senada dengan pendapat di atas, al-Syathibi, seorang pakar hukum Islam dari kalangan Mazhab Maliki, mengembangkan doktrin maqashid al-syari'ah dengan menjelaskan bahwa tujuan akhir hukum Islam adalah satu, yaitu kemaslahatan atau kebaikan dan kesejahteraan umat manusia. Pendapat al-Syathibi didasarkan pada prinsip bahwa Tuhan melembagakan syari'ah (hukum Islam) demi kemaslahatan manusia, baik jangka pendek maupun jangka panjang. ${ }^{26}$ Eksistensi perlindungan hukum hak anak dalam institusi keluarga menjadi sangat penting, karena keluarga dihadirkan dengan prinsip mu'asyarah bi alma'ruf.

Bila dilihat dari tujuan hukum terhadap hak perlindungan anak, maka ketetapan hukum yang dibuat oleh Allah SWT dan Nabi Muhammad SAW baik yang termuat dalam Al-Qur'an atau Al-Hadis yaitu untuk kebahagiaan dunia dan akhirat, dengan jalan mengambil segala yang bermanfaat dan mencegah serta menolak segala yang tidak berguna bagi kehidupan manusia (kemaslahatan manusia). Berdasaarkan tujuan hukum Islam di atas, dapat dirumuskan bahwa tujuan hukum Islam adalah memelihara jiwa, akal, harta masyarakat secara umum, dan keturunan. Oleh karena itu, kedudukan hukum Islam amat penting dalam kehidupan bermasyarakat. Sebab, empat dari lima tujuan syariat yang disebutkan di atas, hanya dapat dicapai dengan mentaati ketentuan hukum Islam, dua di antaranya bertautan dengan ketentuan hukum perdata Islam, yaitu harta dan keturunan, sementara akal dan jiwa semata-mata dalam ranah ketentuan hukum pidana Islam. ${ }^{27}$

Dari paparan di atas, dapat disimpulkan bahwa hakikat perlindungan anak dalam hukum Islam adalah pemenuhan hak-hak anak dan perlindungannya dari hal-hal yang dapat membahayakan diri, jiwa, dan hartanya, yang mencakup aspek fisik, mental, spiritual, dan sosial anak. Adapun hak perlindungan anak dalam hukum Islam

${ }^{24}$ M. Hasbi Ash-Shieddieqy, (Filsafat Hukum Islam (Jakarta: Bulan Bintang, 1976), 188.

${ }^{25}$ Mukhtar Yahya and Fatchurrahman, Dasar-Dasar Pembinaan Hukum Fiqh Islami (Bandung: Al-Ma'arif, 1993), 333.

${ }^{26}$ Muhammad Khalid Mas'ud, Filsafat Hukum Islam Dan Perubahan Sosial, trans. Yudian W. Asmin (Surabaya: Al-Ikhlas, 1995), 225.

${ }^{27}$ Zainuddin Ali, Hukum Pidana Islam (Jakarta: Sinar Grafika, 2007), 13-14 
diantaranya; 1). Hak anak yang paling utama dalam Islam adalah hak perlindungan. ${ }^{28}$ 2). Hak untuk hidup 3). Hak mendapat kejelasan nasab. 4) Hak mendapatkan pemberian nama yang baik, Memberikan nama merupakan kewajiban setiap orang tua. 5). Hak memperoleh ASI, Islam memberikan hak pada seorang anak bayi untuk mendapatkan ASI maksimal selama dua tahun. 6). Hak anak dalam mendapatkan asuhan, perawatan dan pemeliharaan. 7). Hak anak dalam kepemilikan harta benda. 8). Hak anak dalam memperoleh pendidikan dan pengajaran. ${ }^{29}$

Intinya Islam memperhatikan masalah anak tidak hanya setelah anak dilahirkan, tetapi bahkan sejak anak itu belum merupakan suatu bentuk. Syariat Islam memberikan perlindungan yang sangat besar terhadap janin yang berada dalam rahim ibu, baik perlindungan jasmaniah maupun rohaniyah sehingga janin tersebut dapat tumbuh dan berkembang dengan baik yang pada akhirnya lahir ke dunia dengan sempurna. ${ }^{30}$ Periode pranatal merupakan masa yang mengandung banyak bahaya, baik fisik maupun psikologis. Meskipun tidak dapat di klaim bahwa periode ini merupakan periode yang paling berbahaya- tetapi jelas bahwa periode ini merupakan masa dimana bahayabahaya lingkungan atau bahaya psikologis dapat sangat mempengaruhi pola perkembangan selanjutnya atau bahkan dapat mengakhiri suatu perkembangan. ${ }^{31}$ Oleh karena itu Islam memberikan hak-hak kepada janin diantaranya adalah dimuliakan, dijaga dan dilindungi sebelum lahir ke dunia ini dari segala tindakan bodoh yang dilakukan oleh orang-orang murtad, sesat lagi kufur terhadap segala nikmat yang telah diberikan oleh Allah SWT. Ajaran syariat Islam tidak berhenti sampai di situ, ia juga memerintahkan kepada ulil amri (pejabat setempat ) untuk ikut serta melindungi, memperhatikan situasi dan kondisi ibu hamil. Berbuat baik kepada ibu hamil adalah wajib, kalau sang ibu melakukan tindakan kriminal dan pemerintah hendak menjatuhkan hukuman kepadanya hendaklah jangan sampai mengganggu atau mempengaruhi kondisi kesehatan janin yang ada dalam kandungannya. ${ }^{32}$

Ketentuan UndangUndang Nomor 23 Tahun 2002 dapat diketahui bahwa anak yang ada dalam kandungan hingga berusia 18 tahun mendapat perlindungan akan hakhak hidup, tumbuh, dan berkembang, serta dari berbagai kekerasan dan diskriminasi. Batasan ini menunjukkan bahwa upaya perlindungan yang dilakukan hanyalah sebatas perlindungan duniawi dan material saja. Pertanyaannya adalah bagaimana dengan perlindungan terhadap kehidupan akhirat dan moral anak. Di sinilah agaknya letak keunggulan Islam yang mempunyai aturan yang ditujukan untuk memberikan

28 Perlindungan di sini terutama dari segala situasi dan kondisi yang tidak menguntungkan, yang dapat membuat anak menjadi terlantar atau membuatnya menjadi manusia yang dimurkai Tuhan. Islam mengajarkan agar upaya perlindungan dan pengasuhan anak dilakukan jauh sebelum kelahirannya ke muka bumi. Ini dimulai dengan memberi tuntunan kepada manusia dalam memilih pasangan hidup. Laki-laki dan perempuan dianjurkan untuk memilih pasangan hidup dari orang-orang yang baik; berakhlak mulia dan beramal saleh. Islam menjunjung tinggi hak perlindungan setiap manusia, Banyak ayat al-Qur'an yang menegaskan larangan untuk membunuh jiwa manusia, baik itu anak sendiri ataupun orang lain.

${ }^{29}$ Sholihah and Ag, "Perlindungan Anak Dalam Perspektif Hukum Islam."

${ }^{30}$ Abu Hadiyan Shafiyarrahman, Hak-Hak Anak dalam Syari'at Islam (Yogyakarta : Al-Manar, 2003), 25

${ }^{31}$ Elizabeth B. Hurlock, Psikologi Perkembangan (Jakarta : Erlangga, tth), 28.

${ }^{32}$ Gamin, "Perhutanan Sosial Di Indonesia Dalam Perspektif Islam." 
perlindungan bagi manusia, termasuk anak, bagi kesejahteraan hidup dunia maupun akhirat. Allah menggambarkan dalam surah al-Qashash ayat 77 yang berbunyi :

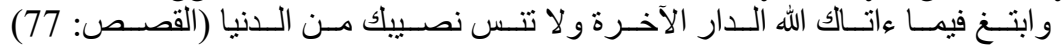

Artinya : " dan carilah apa yang telah dianugerahkan Allah untuk kepadamu (kebahagiaan negeri

akhirat, dan janganlah kamu melupakan bahagianmu dari (keni’matan) duniawi"

Pandangan Islam hidup duniawi dan ukhrawi merupakan satu kesatuan. Pertama, dunia tempat menanam dan akhirat tempat menuai. Apa yang anda tanam di sini, akan memperoleh buahnya di sana. Islam tidak mengenal istilah amal dunia dan amal akhirat.... Kedua, adalah suatu hal yang penting untuk mengarahkan pandangan kepada akhirat sebagai tujuan dan kepada dunia sebagai sarana untuk mencapai tujuan... Ketiga, ayat di atas menggunakan redaksi yang bersifat aktif ketika berbicara tentang kebahagiaan akhirat bahkan menekankannya dengan perintah untuk bersungguhsungguh dan dengan sekuat tenaga berupaya meraihnya. Sedangkan perintah menyangkut kebahagiaan duniawi berbentuk pasif. Hal ini mengesankan perbedaan antara keduanya". 33

\section{Implementasi Hak Perlindungan Anak dalam Hukum Negara}

Negara Kesatuan Republik Indonesia dalam menjamin kesejahteraan pada setiap warga negaranya salah satunya adalah dengan memberikan perlindungan terhadap hak anak yang merupakan salah satu dari hak asasi manusia. Pemerintah Indonesia dalam usahanya untuk menjamin dan mewujudkan perlindungan dan kesejahteraan anak adalah melalui pembentukan Undang-Undang Nomor 23 Tahun 2002 tentang Perlindungan Anak. Dan dalam rangka penyesuaian terhadap beberapa ketentuan maka dilakukan beberapa perubahan terhadap pasal-pasal tertentu maka diundangkan Undang-Undang nomor 35 Tahun 2014 tentang perubahana atas UndangUndang Nomor 23 Tahun 2002 tentang Perlindungan Anak. Perlindungan Anak tersebut adalah segala kegiatan untuk menjamin dan melindungi anak dan hak-haknya agar dapat hidup, tumbuh, berkembang, dan berpartisipasi secara optimal sesuai dengan harkat dan martabat kemanusiaan, serta mendapat perlindungan dari kekerasan dan diskriminasi.

Dalam Undang-Undang Perlindungan Anak pelanggaran terhadap perlindungan hak-hak anak, selain merupakan pelanggaran hak-hak asasi manusia juga penghalang yang sangat besar bagi kelangsungan hidup dan perkembangan anak. Ahmad Kamil menjelaskan bahwa Perlindungan Anak merupakan pertanggungjawaban orang tua, keluarga, masyarakat, pemerintah dan negara yang merupakan rangkaian kegiatan yang dilaksanakan secara terus menerus demi terlindunginya hak-hak anak. ${ }^{34}$ Pengawasan ekstra terhadap anak baik secara pribadi maupun sebagai bagian dari masyarakat, perlu dilakukan. Hal tersebut ditujukan untuk melindungi hak-hak anak serta mencegah masuknya pengaruh eksternal yang negatif yang dapat mengganggu

${ }^{33}$ Hadiyah Salim, Mukhtar al-Ahadits (Bandung: al-Maarif, 1983), 286

34 Ahmad Kamil dan Fauzan, Hukum Perlindungan dan Pengangkatan Anak di Indonesia (PT RajaGrafindo Persada. Jakarta 2008), 5. 
tumbuh kembang anak. ${ }^{35}$ Perlindungan anak sebagaimana batasan pengertian yang tercantum dalam Pasal 1 angka 2 Undang-Undang tentang Perlindungan Anak dapat terwujud apabila mendapatkan dukungan dan tanggung jawab dari berbagai pihak. Dukungan yang dibutuhkan guna mewujudkan perlindungan atas hak anak di Indonesia diatur Pasal 20 UUPA tersebut menyebutkan bahwa negara, pemerintah, pemerintah daerah, masyarakat, keluarga, dan orang tua atau wali berkewajiban dan bertanggung jawab terhadap penyelenggaraan perlindungan anak.

Negara dan Pemerintah Republik Indonesia mempunyai kewajiban dan tanggung jawab untuk menghormati dan menjamin hak asasi setiap anak tanpa membedakan suku, agama, ras, golongan, jenis kelamin, etnik, budaya dan bahasa, status hukum anak, urutan kelahiran anak, dan kondisi fisik dan/atau mental. Negara dan pemerintah juga berkewajiban serta bertanggungjawab untuk memberikan dukungan sarana dan prasarana dalam penyelenggaraan perlindungan anak. Pengaturan mengenai kewajiban dan tanggung jawab negara dan pemerintah tercantum dalam ketentuan Pasal 21 dan Pasal 22 Undang-Undang tentang Perlindungan Anak. Pasal 23 dan Pasal 24 Undang-Undang tentang Perlindungan Anak mengatur mengenai jaminan negara dan pemerintah atas penyelenggaraan perlindungan anak. Negara dan pemerintah menjamin perlindungan, pemeliharaan dan kesejahteraan anak dengan memperhatikan hak dan kewajiban orang tua, wali, atau orang lain yang secara hukum bertanggungjawab terhadap anak. Negara dan pemerintah juga menjamin anak untuk menggunakan haknya dalam menyampaikan pendapat sesuai dengan usia dan tingkat kecerdasan anak. Jaminan yang diberikan oleh negara dan pemerintah tersebut diikuti pula dengan pengawasan dalam penyelenggaraan perlindungan anak. ${ }^{36}$

konsep perlindungan anak meliputi ruang lingkup yang luas, dalam arti bahwa perlindungan anak tidak hanya mengenai perlindungan atas raga dan jiwa anak, tetapi mencakup pula perlindungan atas semua hak serta kepentingannya yang dapat menjamin pertumbuhan dan perkembangan yang wajar, baik secara rohani, jasmani maupun sosial sehingga diharapkan anak Indonesia akan berkembang menjadi orang dewasa Indonesia yang mampu dan mau berkarya untuk mencapai dan memelihara tujuan pembangunan Nasional tersebut diatas. jelas bahwa perlindungan anak menyakut pula aspek pembinaan generasi muda dan masalah Nasional yang memerlukan penataan dalam suatu sistem terpadu dan terkoordinasi dengan baik.

Adapun hak-hak anak yang perlu dilindungi diantaranya (1) Hak terhadap kelangsungan hidup (survival rights). Hak kelangsungan hidup berupa hak-hak anak untuk melestarikan dan mempertahankan hidup dan hak untuk memperoleh standar kesehatan tertinggi dan perawatan yang sebaik-baiknya. Konsekwensinya menurut Konvensi Hak-hak Anak, negara harus menjamin kelangsungan hak hidup, dan perkembangan anak (Pasal 6). Disamping itu Negara berkewajiban untuk menjamin hak atas tarap kesehatan tertinggi yang bisa dijangkau, dan melakukan pelayanan kesehatan dan pengobatan, khususnya perawatan kesehatan primer (Pasal 24). (2) Hak terhadap perlindungan (protection rights). (3) Hak untuk tumbuh berkembang (development rights) Hak untuk tumbuh kembang meliputi segala bentuk pendidikan (formal maupun

${ }^{35}$ Hardjon, Perlindungan Hukum Terhadap Anak (Eresco: Jakarta, 2007), 5.

36 Fitriani, "Peranan Penyelenggara Perlindungan Anak Dalam Melindungi Dan Memenuhi Hak-Hak Anak." 
non formal) dan hak untuk mencapai standar hidup yang layak bagi perkembangan fisik, mental, spiritual, moral dan social anak (4) Hak untuk Berpartisipasi (participation rights). Bahkan hukum nasional menjelaskan bahwa implementasi perlindungan hukum terhadap anak meliputi tindakan pencegahan dan tindakan represif tetapi yang paling utama adalah tindakan pencegahan. Dengan tindakan pencegahan diupayakan sedemikian rupa agar hal-hal yang merugikan kepentingan dan menimbulkan berbagai penderitaan, mental,fisik dan sosial si anak tidak pernah terjadi, sehingga setiap anak berada dalam keadaan prima untuk menyongsong masa depannya. Melalui Kepres Nomor 36 tahun 1990, Konvensi Hak Anak telah diratifikasi dan berlaku mengikat menjadi hukum Indonesia. ${ }^{37}$

Dengan uraian di atas tampaklah bahwa sesungguhnya usaha perlindungan anak sudah sejak lama ada, baik dalam peraturan dalam bentuk peraturan perundangundangan maupun dalam pelaksanaannya, baik oleh pemerintah maupun organisasi sosial. Namun demikian usaha tesebut belum menunjukan hasil yang memadai sesuai dengan kebutuhan dan perkembangan masyarakat Indonesia. Keadaan ini disebabkan situasi dan kondisi serta keterbatasan yang ada pada pemerintah dan masyarakat sendiri belum memungkinkan mengembangkan secara nyata ketentuan peraturan perundang-undangan yang telah ada. ${ }^{38}$

Di samping perlindungan anak yang bersifat umum, bagi anak dalam situasi dan kondisi darurat wajib memperoleh perlindungan khusus. Undang-undang perlindungan anak telah memberi ukuran bagi anak-anak yang perlu mendapatkan perlindungan khusus dalam hal pemerintah dan lembaga negara lainnya berkewajiban dan bertanggung jawab untuk memberikan perlindungan khusus kepada anak dalam situasi darurat, anak yang berhadapan dengan hukum, anak dari kelompok minoritas dan terisolasi, anak tereksplotasi secara ekonomi dan/seksual anak yang diperdagangkan, anak korban kekerasan fisik dan/atau mental, dan anak korban perlakuan salah dan penelantaran. Secara lebih perinci hak-hak anak dalam UU Nomor 23 tahun 2002 sebelum adanya pembaharuan adalah sebagai berikut:

1) Hak untuk dapat hidup, tumbuh, berkembang, dan berpartisipasi secara wajar sesuai dengan harkat dan martabat kemanusiaan, serta mendapat perlindungan dari kekerasan dan diskriminasi (Pasal 4). Sejalan dengan KHA, ${ }^{39}$ hak hidup bagi anak ini, dalam wacana instrumen/konvensi Internasional merupakan hak asasi yang universal, dan dikenali sebagai hak yang utama (supreme right). Sedangkan hak atas tumbuh kembang diturunkan ke dalam hak atas kesehatan, pendidikan, dan hak untuk berekspresi, dan memperoleh informasi. Dalam UUPA, turunan hak atas tumbuh kembang ini diwujudkan dalam penyelenggaraan perlindungan dalam bidang pendidikan, kesehatan, dan sosial, termasuk agama.

2) Hak atas suatu nama sebagai identitas diri dan status kewarganegaraan (Pasal 5).

${ }^{37}$ Hukum, Ham, and Pengantar, “Aspek Hukum Perlindungan Tehadap Anak.”

${ }^{38}$ Wagiati Soetodjo, Hukum Pidana Anak ( Bandung, PT Refika Aditama, 2008), Cet.

II, 67.

${ }^{39} \mathrm{https} / /$ www.google.co.id/search?q=konvensi+hak+anak+PBB\&oq=konvensi+hak+a nak+PBB\&aqs=chro e..69i57.13573j0j8\&sourceid=chrome\&ie=UTF-8. Diakses tanggal 5 April 2020 
3) Hak untuk beribadah menurut agamanya, berpikir, dan berekspresi sesuai dengan tingkat kecerdasan dan usianya, dalam bimbingan orang tua (Pasal 6). Hak untuk beribadah menurut agamanya, berfikir dan berekspresi merupakan wujud dari jaminan dan penghormatan negara terhadap hak anak untuk berkembang, yang mengacu kepada Pasal 14 KHA.

4) Hak untuk mengetahui orang tuanya, dibesarkan, dan diasuh oleh orang tuanya sendiri (Pasal 7).

5) Hak memperoleh pelayanan kesehatan dan jaminan sosial sesuai dengan kebutuhan fisik, mental, spiritual, dan sosial (Pasal 8).

6) Hak memperoleh pendidikan dan pengajaran dalam rangka pengembangan pribadinya dan tingkat kecerdasannya sesuai dengan minat dan bakatnya (pasal 9).

7) Khusus bagi anak yang menyandang cacat juga berhak memperoleh pendidikan luar biasa, sedangkan bagi anak yang memiliki keunggulan juga berhak mendapatkan pendidikan khusus (Pasal 9 ayat 2).

8) Setiap anak yang menyandang cacat berhak memperoleh rehabilitasi, bantuan sosial, dan pemeliharaan taraf kesejahteraan sosial (Pasal 12).

9) Hak menyatakan dan didengar pendapatnya, menerima, mencari, dan memberikan informasi sesuai dengan tingkat kecerdasan dan usianya demi pengembangan dirinya sesuai dengan nilai-nilai kesusilaan dan kepatutan (Pasal 10).

10) Hak untuk beristirahat dan memanfaatkan waktu luang, bergaul dengan anak yang sebaya, bermain, berekreasi, dan berkreasi sesuai dengan minat, bakat, dan tingkat kecerdasannya demi pengembangan diri (Pasal 11).

11) Setiap anak selama dalam pengasuhan orang tua, wali, atau pihak lain manapun yang bertanggung jawab atas pengasuhan, berhak mendapat perlindungan dari perlakuan yang menyimpang (Pasal 13).

12) Hak untuk diasuh oleh orang tuanya sendiri, kecuali jika ada alasan dan/atau aturan hukum yang sah menunjukkan bahwa pemisahan itu adalah demi kepentingan terbaik bagi anak dan merupakan pertimbangan terakhir (Pasal 14).

13) Hak untuk memperoleh perlindungan dari pelibatan dalam situasi darurat atau kerusuhan (pasal 15).

14) Hak untuk memperoleh perlindungan dari sasaran penganiayaan, penyiksaan, atau penjatuhan hukuman yang tidak manusiawi, hak untuk memperoleh kebebasan sesuai dengan hukum dan perlindungan dari penangkapan, penahanan, atau tindak pidana penjara anak hanya dilakukan apabila sesuai dengan hukum yang berlaku dan hanya dapat dilakukan sebagai upaya terakhir (Pasal 16).

15) Setiap anak yang menjadi korban atau pelaku kekerasan seksual atau yang berhadapan dengan hukum berhak dirahasiakan (Pasal 17 ayat 2).

16) Setiap anak yang menjadi korban atau pelaku tindak pidana berhak mendapatkan bantuan hukum dan bantuan lainnya (Pasal 18).

\section{Respon Islam dalam Hak perlindungan Anak Upaya Perubahan Sosial}

Islam sebagai agama yang penuh dengan kebijakan merespons perkembangan perundang-undangan terkait dengan hak-hak perlindungan anak. Nampak jelas bahwa secara umum, hak-hak anak yang terdapat dalam Undang-Undang Perlindungan Anak 
sejalan dengan hak-hak anak dalam hukum Islam. Namun, sebagaimana dijelaskan di atas, Undang-Undang Perlindungan Anak tidak memberikan penekanan yang tegas akan hak anak untuk memperoleh pendidikan dan bimbingan agama dari orang tua mereka dan bentuk perlindungan anak dalam keluarga juga belum dirumuskan secara jelas. Pasal 6 Undang-Undang ini menyatakan bahwa "setiap anak berhak untuk beribadah menurut agamanya, berpikir, dan berekspresi sesuai dengan tingkat kecerdasan dan usianya, dalam bimbingan orang tua". Pasal ini mengandung ketentuan yang lebih menekankan pada "kebebasan anak" (termasuk dalam masalah agama), bukan pada kewajiban orang tua untuk membimbing anak-anak mereka. Hal ini diperkuat dengan tidak adanya ketentuan yang berkaitan dengan kewajiban orang tua untuk membimbing anak-anak mereka dalam hal agama, sebagaimana dirumuskan pada Pasal 26 Undang-Undang ini. Di lain pihak, Undang-Undang ini memberikan perhatian yang besar tentang kewajiban dan tanggung jawab orang tua dalam perlindungan anak.

Hak atas perlindungan (hak) dari penyalahgunaan kekuasaan telah diatur dalam Islam. Sudah berabad-abad yang lalu, Islam mengakui bahwa setiap keputusan, aturan, dan prosedur, dari penguasa publik di setiap jenjang tidak sah atau tidak mengikat secara legal apabila mereka tidak konsisten dengan hukum (syari'at). Tentu saja berkaitan dengan konsep 'perlindungan hak'. Sebagaimana dalam setiap masyarakat yang didasarkan atas norma dan prosedur demokratik, hukum Islam menyatakan bahwa "engkau tidak bisa mencabut kehidupan, kebebasan, atau kepemilikan seseorang kecuali melalui 'proses hukum yang sah'. ${ }^{40}$

Apabila perubahan sosial menyangkut aspek hukum dan pengaruh dari perubahan sosial, maka keberadaan hukum dituntut untuk merespons segala problematika dan berbagai persilangan kepentingan yang ada dan terjadi di masyarakat. Disadari bahwa hukum sebagai alat rekayasa sosial (social engineering by law) harus berdasarkan aspirasi masyarakat yang selalu berkembang dan berubah sesuai dengan dinamika masyarakat yang bersangkutan. Untuk mencapai hal tersebut, diperlukan kesadaran hukum, proses perubahan hukum dan kepastian hukum sehingga terpenuhinya kebutuhan dasar kesejahteraan, kemakmuran dan keadilan. Hal ini dilakukan agar hukum dan perubahan masyarakat tidak berada pada ruang hampa dan harus didekatkan dengan kehidupan nyata di masyarakat. Setiap aturan maupun norma yang ada di dunia ini mempunyai tujuan. Sama halnya dengan norma hukum atau hukum itu sendiri. Dalam konteks hukum Islam, tujuan hukum menurut para ulama yaitu diantaranya: Mendidik jiwa, Mensucikan manusia, Menegakkan keadilan, Merealisir kemaslahatan, dan kebahagiaan di dunia-akhirat. Tujuan ini sejalan dengan pemberian hukuman dalam Islam sesuai dengan konsep tujuan umum disyaritkannya hukum, yaitu untuk merealisasi kemaslahatan umat dan sekaligus menegakkan keadilan. ${ }^{41}$

Demikian juga hak perlindungan anak dalam hukum negara, hukum Islam menanamkan terhadap nilai-nilai kemaslahatan yang di dalamnya mengandung unsur memelihara agama, akal, jiwa, keturunan, dan harta yang dapat dijelaskan bahwa korelasi yang signifikan hak perlindungan anak dalam agama, menunjukkan bahwa

${ }^{40}$ C.G. Weeramantry, Hak Asasi Manusia Internasional: Beberapa Perspektif Islam (Kolombo: Lecture, 1986), 23.

${ }^{41}$ Pertunjukan, "Kabupaten Wonosobo." 
melindungi hak anak dalam konsep hukum Islam merupakan suatu kewajiban bagi keluarga, masyarakat dan negara terkait pendidikan agama dan bertanggungjawab besar untuk bertakwa dan ber ta' affuf. Pendidikan ketakwaan pada sosok seorang anak tidak hanya terjabarkan dalam shalat, zakat dan sedekah, melainkan juga pada perilaku keagamaan. Menjaga jiwa, Garis kemiskinan dan terlantarnya anak adalah masalah terbesar pembangunan di Negara-negara Muslim. Kemiskinan juga bertentangan dengan maqashid syariah (menjaga jiwa/ nafs). Ijma' ulama mewajibkan masyarakat Muslim secara fardh kifayah untuk mengayomi kaum fakir miskin. Memelihara akal, Perlindungan anak, terutama dalam pendidikan merupakan keharusan yang tidak bisa ditawar. Urgensi kemaslahatan pendidikan bagi anak, tidak hanya terkait dengan anak sebagai individu, namun juga sebagai warga Negara yang harus dilndungi hak-hak pendidikannya agar seorang anak menjadi cerdas. Perlindungan anak dalam suatu Negara merupakan tolak ukur mutu suatu bangsa. Karenanya, perlindungan anak dalam negara, sejatinya tidak akan sia-sia terhadap kemajuan pendidikan anak dan lingkungan di sekitarnya. Secara langsung atau tidak, perkembangan ini akan berefek terhadap kecerdasan dan kemajuan diri sendiri, keluarga dan umat Islam pada umumnya.

Memelihara keturunan, Seorang ibu yang melahirkan anak sudah tentu harus memlihara keturunannya dalam hal ini memberikan perlindungan terhadap keturunan yang baik dengan melaksanakan kewajibannya orang tua dianggap sudah memelihara keturanan sesuai nilai-nilai maslahat dalam hukum Islam. Memelihara harta, Konsep pemeliharaan harta dalam konteks modern, tidak hanya menjaga harta benda, dari kehilangan atau kerusakan, malainkan juga perintah kepada pemerintah untuk menggerakkan aksi bahu-membahu, persamaan dan penghapusan jurang pemisah antar tingkat sosial ekonomi, sehingga dapat memenuhi unsur-unsur kecukupan yang pada gilirannya dapat mendorong pertumbuhan ekonomi. Negara memberikan hak perlindungan anak dengan melakukan langkah-langkah melalui pendidikan, kesehatan, sosial, ekonomi dan pelayanan dalam bentuk lainnya. Hukum Islam memberikan perhatian yang besar mengenai pemeliharaan dan perlindungan anak. Hal ini dapat dilihat dari beberapa nash al-Qur'an dan Hadits yang berkenaan dengan hak-hak anak, sebagai dasar pijakan pelaksanaan perlindungan anak karena hakikat perlindungan anak adalah pemenuhan hak hak anak tersebut.

Peraturan hak perlindungan anak merupakan upaya adanya perubahan sosial dalam masyarakat agar adanya keteraturan upaya melindungi hak anak sesuai amanat Undang-undang Dasar sebagai hukum dasar (konstitusi) yang berperan sebagai landasan tertib hukum suatu negara. Dengan demikian maka kehidupan kebangsaan yang bebas sebagaimana diamanatkan dalam Pembukaan Undang-undang Dasar 1945 adalah kehidupan kebangsaan bebas berlandaskan pada tertib hukum. Undang-Undang Dasar tahun 1945 merupakan konstitusi, sebagai hukum dasar sekaligus merupakan bukti adanya pembaharuan hukum di Indonesia dalam upaya perlindungan hak anak, dan perubahan sosial yang terjadi di dalam suatu masyarakat. Menurut teori hukum, bahwasanya hukum memainkan peranan yang penting dalam suatu masyarakat, dan bahkan mempunyai multifungsi untuk kebaikan masyarakat, demi mencapai keadilan, kepastian hukum, ketertiban, kemanfaatan, dan lain-lain tujuan hukum. Akan tetapi, keadaaan sebaliknya dapat terjadi bahkan sering terjadi, dimana penguasa negara 
menggunakan hukum sebagai alat untuk menekan masyarakat, agar masyarakat dapat dihalau ketempat yang diinginkan oleh penguasa negara. Perubahan sosial dalam hubungannya dengan sektor hukum merupakan salah satu kajian penting dari disiplin Sosiologi Hukum.

Hubungan antara perubahan sosial dan sektor hukum tersebut merupakan hubungan interaksi, dalam arti terdapat pengaruh perubahan sosial terhadap perubahan sektor hukum sementara di lain pihak perubahan hukum juga berpengaruh terhadap suatu perubahan sosial. Perubahan hukum yang dapat memengaruhi perubahan sosial sejalan dengan salah satu fungsi hukum, yakni fungsi hukum sebagai sarana perubahan sosial atau sarana rekayasa masyarakat (social engineering). ${ }^{42}$

Seiring dengan Undang-undang hak-hak perlindungan anak dalam sistem hukum Indonesia dapat memengaruhi, bahkan menjadi control sosial dalam kehidupan masyarakat. Bahkan Roscoe Pound menyatakan bahwa kontrol sosial diperlukan untuk menguatkan peradaban masyarakat manusia karena mengendalikan perilaku antisosial yang bertentangan dengan kaidah-kaidah ketertiban sosial. Hukum, sebagai mekanisme kontrol sosial, merupakan fungsi utama dari negara dan bekerja melalui penerapan kekuatan yang dilaksanakan secara sistematis dan teratur oleh agen yang ditunjuk untuk melakukan fungsi itu. Akan tetapi, Pound menambahkan bahwa hukum saja tidak cukup, ia membutuhkan dukungan dari institusi keluarga, pendidikan, moral, dan agama. Hukum adalah sistem ajaran dengan unsur ideal dan empiris, yang menggabungkan teori hukum kodrat dan positivistik. ${ }^{43}$

Hukum Islam tidak menolak jika perwujudan hukum tersebut untuk kemaslahatan masyarakat dengan harapan adanya ketertiban dan keadilan dengan perubahan hukum yang sesuai dengan nilai-nilai hukum Islam. Sejalan dengan konsep tahqiq problematika kemanusiaan atau merealisasikan kemaslahatan umat manusia. Dapat dipahami dengan jelas bahwa prinsip keadilan merupakan kata kunci dalam hukum Islam. Meski harus diakui bahwa manusia kadang-kadang mengalami kesulitan untuk menangkap prinsip-prinsip dan norma-norma keadilan yang ditujukan Tuhan dalam syariat Nya menurut aturan nalarnya, terlebih lagi yang menyangkut hubungan vertikal manusia dengan Khaliknya. Sebagai sebuah ideologi sosial, Islam memiliki konsep tentang masyarakat ideal dan karenanya Islam juga berkepentingan untuk merubah masyarakat menuju cita-cita idealnya. Gagasan kemasyarakatan itu misalnya terangkum dalam konsep ummah sebagaimana termuat dalam al-Qur'an dan kemudian diobyektivikasikan dalam prasis pembentukan Negara Madinah di bawah kepemimpinan Rasulullah Muhammad. ${ }^{44}$

Wallahu a 'lam bisshowaab.

\section{Penutup}

${ }^{42}$ Munir Fuady, Sosiologi Hukum Kontemporer "Interaksi Hukum, Kekuasaan, dan Masyarakat”, (Jakarta: Kencana, 2011), 61.

${ }^{43}$ Lathif, "Teori Hukum Sebagai Sarana Alat Untuk Memperbaharui Atau Merekayasa Masyarakat."

${ }^{44}$ Asrori S. Karni, "Pendahuluan", Civil Society dan Ummah; Sintesa Diskursif "Rumah" Demokrasi, 8. 
Respon hukum Islam terhadap hak perlindungan anak menjadi cerminan dari tuntutan global karena perlindungan anak menjadi masalah besar dan mendesak yang harus diagendakan sesuai peraturan atau perundangan untuk melindungi segenap warga masyarakat. Hukum Islam telah lebih dahulu mengajarkan umat manusia tentang menjaga dan melindungi masyarakat terkait dengan hak perlindungan anak. Bahkan konsep dan peraturan tentang anak pun disinyalir diadopsi oleh Barat melalui pemunculan ide-ide universal yang dibakukan dalam konvensi Universal Declaration of Human Rights. Perundangan hak perlindungan anak dalam system hukum negara sudah memenuhi criteria dan sudah mengadopsi nilai-nilai hukum Islam di dalamnya, terkait masalah hak perlindungan anak, pada dasarnya sejalan dengan hak-hak anak yang terdapat dalam hukum Islam, bahkan lebih komplek menjelaskannya yang terakumulasi dalam nilai-nilai kemaslahatan.

Bahkan implementasinya pun dijalankan oleh segenap lembaga-lembaga pemerintah dalam upaya melindungi hak-hak anak, bahkan institusi agama dianggap punya peran penting dalam menyikapi masalah perlindungan terhadap anak, khususnya perlindungan terhadap hak-hak anak dari kekerasan yang terjadi baik dalam keluarga maupun lingkungan masyarakat. Hal ini didasari oleh pemahaman bahwa agama Islam bahkan agama apapun tidak pernah menyetujui dan menerima berbagai bentuk tindakan kekerasan anak. Agama memiliki kebenaran dan kesucian, agama juga sangat menghormati dan menghargai keadilan, karena agama pada dasarnya mengajarkan penghargaan martabat manusia dan perlindungan terhadap seluruh ciptaan, menghapus diskriminasi, ketidakadilan, pelanggaran hak asasi manusia dan pemasungan kebebasan anugerah Tuhan yang akan mengakibatkan kerusakan, kehancuran dan eksplotasi terhadap ciptaan Tuhan utamanya manusia.

\section{Referensi}

Anak, Perlindungan, and D A N Hukum. "Perbandingan Hak-Hak Anak Menurut Undang- Undang Nomor 23 Tahun 2002 Tentang Perlindungan Anak Dan Hukum Islam" 1 , no. 2 (2018): 88-111. https://doi.org/10.5281/zenodo.3554863.

A Partanto, Pius, dan M Dahlan Al Barry, Kamus Ilmiah Populer, Surabaya: Arkola, 1994.

al-Ghazali, Abu Hamid, al-Mustashafa fi 'ilm al-Ushul, Beirut: Dar al-Kutub alIlmiyyah, 1983.

Ali, Zainuddin, Hukum Pidana Islam, Jakarta: Sinar Grafika, 2007.

al-Jaziri, Abdurrahman, Kitab al-Fiqh `alā al-Mazāhib al-Arba`ah, Kairo: Dar alHadits, Tanpa Tahun, Juz. IV.

al-Syathibi, Abu Ishaq, al-Muwafaqat fi Ushul al-Syari'ah, Kairo: Musthafa Muhammad, tt.

al-Zuhaily, Wahbah, al-Fiqh al-Islami wa Adilatuhu, Damsyik: Dar al-Fikr, 1409 H/1989 M, Cet. III.

Anshari, Ibn, Perlindungan Anak Menurut Perspektif Islam, Jakarta, Komisi Perlindungan Anak Indonesia.

Ash-Shieddieqy, M. Hasbi, Filsafat Hukum Islam, Jakarta: Bulan Bintang, 1976.

B. Hurlock, Elizabeth, Psikologi Perkembangan, Jakarta : Erlangga, tth. 
C.G. Weeramantry, Hak Asasi Manusia Internasional: Beberapa Perspektif Islam, Kolombo: Lecture, 1986.

Farid, Rafat, al-Islam wa Huquq al-Thifi, Kairo: Dar Muhaysin, 2002.

Fuady, Munir, Sosiologi Hukum Kontemporer "Interaksi Hukum, Kekuasaan, dan Masyarakat”, Jakarta: Kencana, 2011.

Fitriani, R. "Peranan Penyelenggara Perlindungan Anak Dalam Melindungi Dan Memenuhi Hak-Hak Anak." Jurnal Hukum Samudra Keadilan 11, no. 2 (2016): 250-358.

Gamin. "Perhutanan Sosial Di Indonesia Dalam Perspektif Islam.” Jurnal Kajian Peradaban Islam 2, no. 1 (2019): 18-28.

Gosita, Arif, Masalah Perlindungan Anak, Jakarta: Akademika Prssindo, 1985.

Hardjon, Perlindungan Hukum Terhadap Anak, Eresco: Jakarta, 2007.

Herlina, Apong, dkk dan UNICEF, Perlindungan Anak, Jakarta: tp , 2003.

Husein al-Fatlawi, Suhail, Huquq al-Insan fi al-Islam, Beirut: Dar al-Fikr al-'Arabi, 2001, Cet. I

Hukum, Departemen, D A N Ham, and Kata Pengantar. "Aspek Hukum Perlindungan Tehadap Anak," 2009.

Kamil, Ahmad, dan Fauzan, Hukum Perlindungan dan Pengangkatan Anak di Indonesia, PT Raja Grafindo Persada. Jakarta 2008.

Khalid Mas'ud, Muhammad, Filsafat Hukum Islam Dan Perubahan Sosial, trans. Yudian W. Asmin, Surabaya: Al-Ikhlas, 1995.

Khalid Mas'ud, Muhammad, Islamic Legal Philosophy, Islamabad: Islamic Research Institut, 1977.

Lathif, Nazaruddin. "Teori Hukum Sebagai Sarana Alat Untuk Memperbaharui Atau Merekayasa Masyarakat." Palar | Pakuan Law Review 3, no. 1 (2017): 73-94. https://doi.org/10.33751/palar.v3i1.402.

Manzhur, Ibn, Lisan al- 'arab, Mesir: Dar al-Mishriyah li al-Ta'lif wa al-Tarjamah, tt, Juz. 2.

Pertunjukan, Fakultas Seni. "Kabupaten Wonosobo,” 2017, 259-83.

Sholihah, Hani, and M Ag. "Perlindungan Anak Dalam Perspektif Hukum Islam" 1, no. 1 (2018): 38-56. https://doi.org/10.5281/zenodo.1161556.

Salim, Hadiyah, Mukhtar al-Ahadits, Bandung: al-Maarif, 1983.

Shafiyarrahman, Abu Hadiyan, Hak-Hak Anak dalam Syari'at Islam, Yogyakarta : AlManar, 2003.

Siregar, Bismar, Aspek Perlindungan atas Hak-hak Anak: Suatu Tinjauan, dalam Hukum dan hak-hak Anak, Jakarta: Rajawali, 1986.

Soetodjo, Wagiati, Hukum Pidana Anak, Bandung, PT Refika Aditama, 2008, Cet. II.

Tim Penyusun Kamus Pusat Pembinaan dan Pengembangan Bahasa, Kamus Besar Bahasa Indonesia, Jakarta : Balai Pustaka,1994.

Undang-Undang HAM 1999 dan Undang-Undang tentang Unjuk Rasa, Bandung: Citra Umbara, 2000.

Undang-undang Republik Indonesia Nomor 23 tahun 2002 tentang Perlindungan Anak, beserta penjelasannya, Bandung: Citra Umbara, 2003. 
Unicef, Pengertian Konvensi Hak Anak, Jakarta: Harapan Prima, 2004.

Wajdi, Muhammad Farid, Dairah al-Ma'arif al-Qarn al-'Isyrin, Beirut: Dar alMa'rifah, 1971, Cet. III.

Yahya, Mukhtar, and Fatchurrahman, Dasar-Dasar Pembinaan Hukum Fiqh Islami, Bandung: Al-Ma'arif, 1993. 